\title{
Cognitive Load Lecture on Diversity and Classification of Vertebrates Through Moodle-Based Online Learning
}

Rifki Risma Munandar*, Teti Rostikawati, Lufty Hari Susanto

Department of Biology Education, Faculty of Teacher Training and Education, Pakuan University, Bogor City, 16129, Indonesia

\section{ARTICLE INFO}

\section{Article history:}

Received: 07 Jan 2021

Revised: 16 Jan 2022

Accepted: 17 Jan 2022

Published online: 24 Jan 2022

\section{Keywords:}

Cognitive Load

Moodle-Based Online Learning

Vertebrate Diversity

Classification

\begin{abstract}
A B S T R A C T
The addition of asynchronous learning hours in e-learning can cause students to have to understand large amounts of material. So that it can be a cognitive burden for students. The purpose of this study was to describe the cognitive load of students during online learning in the subject of vertebrate diversity and classification, especially on the structure of Pisces and amphibians. The research method used in this study was quantitative descriptive by examining the ability to receive and process information, mental effort and the learning outcomes of 46 students of the Biology Education Study Program at Pakuan University. The instrument used in the study was to measure the ability to receive and process information through a test in the form of a task complexity worsheet. Mental effort was measured through a questionnaire (Likert scale) with a range of 1-5. Learning outcomes were measured in the form of an essay test. The results obtained that the learning activities carried out have the characteristics of a high cognitive load component. The high cognitive load obtained by students is seen from the high mental effort and the high intrinsic load possessed by students, so that it has an impact on the learning outcomes obtained.
\end{abstract}

\section{Introduction}

Online learning is something that must be done as an effort to minimize the spread of the Covid-19 virus. Learning designed through distance learning activities, of course, becomes a record for all of us regarding optimizing the implementation of the learning process. Based on the results of quizzes (learning outcomes) given every week to students during learning using e-learning in the Diversity and Vertebrate Classification course, it was found that it was not in line with expectations.

\footnotetext{
* Corresponding author.

E-mail: rifki.munandar@unpak.ac.id
} 
The average quiz value obtained every week is 58 and based on the results of feedback that has been done, several students admit that learning difficulties using e-learning are due to a lot of material being studied and lack of understanding of the material presented. Moreover, the courses taught are vertebrate diversity and classification courses which consist of several subjects so that they require more in-depth studies and explanations, especially in classifying vertebrates. In addition, according to (Aminah, 2018) too much material is also memorized in lessons related to difficult scientific names and names of terms they do not know to be one of the things that cause students to have difficulty learning.

As we know that learning must take place meaningfully. Basically learning is a process of connecting new information with the concepts contained in the cognitive structure (Wardika et al., 2017). However, the addition of asynchronous learning hours in e-learning can cause students to need to understand large amounts of material. Students' working memory plays a very important role in this process. As stated by (Rizvialdi \& Sidarta, 2019) that the memory capacity of each individual is different. Any information that will be processed and stored in working memory consistently. If the information cannot be managed properly in a cognitive schema, it can become a cognitive burden for students.

There are three components of cognitive load that can be measured, namely students' mental effort to describe extraneous cognitive load (ECL), information analysis ability to describe intrinsic cognitive load (ICL), and students' interdisciplinary thinking ability to describe germane cognitive load (GCL). This cognitive load will affect student learning outcomes, information management will also be disrupted along with the disruption of the learning process (Susanto and Munandar, 2017). With this, students will make other efforts to find other information outside of learning.

In addition, several situations can trigger students' mental effort, including; slipt attention situations or conditions where students' attention is divided, transient situations or conditions where students cannot participate in learning due to inappropriate learning stages (Wantika, 2017). Other things that can increase mental effort are external disturbances such as noisy class noises, the way the teacher teaches and the presence of when learning takes place (Nursit, 2015). So that all these things can cause students to have difficulty making efforts that should not be done.

Based on the problems above, a more in-depth analysis is needed to explore the description of students' cognitive load when learning online or using Moodlebased e-learning in the diversity and vertebrate classification courses, especially in the Pisces and amphibian classification material. Then the picture is analyzed more deeply from mental effort, ability to receive and process information, reasoning ability and how the correlation between cognitive load activities. 


\section{Methodology}

The research was conducted using a quantitative descriptive method. The research sample consisted of 46 students of the Biology Education Study Program at Pakuan University, Bogor, West Java in 2020-2021 who were taking lectures on vertebrate diversity and classification. The population in this study were 120 students. The study was conducted in February - June 2021. The ability to receive and process information (ICL) was measured through a test instrument in the form of Task complexity worksheet of the diversity and classification of vertebrates on the topic of Pisces and amphibians. ECL was measured using a Likert scale questionnaire containing statements related to students' mental effort in understanding teaching material with a range of 1-5. Learning outcomes (GCL) were measured using a reasoning test in the form of essay questions by inducing the ability to process information components, integrate information and apply information, can be seen in Table 1 .

Table 1. Instrument

\begin{tabular}{ll}
\hline \multicolumn{1}{c}{ Cognitive Load Components } & \multicolumn{1}{c}{ Instrument } \\
\hline Ability to receive and process information (ICL) & Task complexity worksheet \\
Mental Effort (ECL) & Likert scale questionnaire \\
Learning outcomes (GCL) & essay test \\
\hline
\end{tabular}

Furthermore, the results of the cognitive load measurement were analyzed quantitatively by performing the following statistical tests. (a) Test the mean difference for each component of cognitive load, and (b) Test multivariate correlation and regression between the three components of cognitive load to determine the relationship and contribution between the three components of cognitive load. Then the results of the worksheets and questionnaires that have been obtained are analyzed by comparing and correlated with the scores obtained from the results of the final exam. Based on the results of data processing, a score of mental effort results, the ability to receive and process information and learning outcomes will be obtained that describe the cognitive load of students during the learning process. The value of the level of ability to receive and process information and the learning outcomes obtained are categorized according to the categorization of (Arikunto, 2007), namely Very Good (score 80-100), Good (score 66-79), Enough (score 56-65), Poor (score 40-55), Failed (score 30-39). The value of the level of mental effort obtained is categorized according to the categorization (Munandar, 2015), namely Very low (score 30-39), Low (score 4055), Medium (score 56-65), High (score 66-79), Very high (score 80-100).

To represent cognitive load, it is necessary to compare and correlate between components of cognitive load. The score of the ability to process and process information is higher, the lower the intrinsic cognitive load is represented. A low mental effort score means that the extraneous cognitive load is represented as low. The representation of high reasoning ability indicates a good germane cognitive load. 


\section{Results and Discussion}

Learning activities during the Covid-19 pandemic are a challenge for educators around the world. Online learning activities are a solution that can be done at this time. However, educators must examine in depth the appropriate strategies to be used in the learning process. One of the efforts to facilitate the online learning process is to use a Learning Management System (LMS). The LMS used can be in the form of a paid or free online platform or an LMS developed by the respective educational institutions. Pakuan University as an educational institution has developed an LMS that can help the online learning process. LMS developed using Moodle. In Pakuan University's LMS, there are several additional learning features. One of the added features is a video feature, discussion forum, learning materials, assignments and quizzes which are used as asynchronous learning resources and student activities. The online learning process is also equipped with synchronous meetings through zoom meetings whose links are embedded in the LMS.

Online learning creates a new learning environment that can affect the cognitive processes that occur in students. Likewise, there is a change in the character of students (Suriadi et al., 2021). Online learning has a direct impact on the process and cognitive development of students. The inability to adapt to a new learning process can have an impact on the inhibition of cognitive processes and development (Kahfi, 2021). This condition can represent a cognitive load on students, especially students. The description of the student's cognitive load is seen from 3 components, including: the ability to receive information, mental effort and learning outcomes on the impact resulting from learning activities can be seen in Tabel 2.

Tabel 2. Average Value of Cognitive Load Components

\begin{tabular}{lc}
\hline \multicolumn{1}{c}{ Cognitive Load Components } & Average \\
\hline Ability to receive and process information (ICL) & 59.09 \\
Mental Effort (ECL) & 70.07 \\
Learning outcomes (GCL) & 64.84 \\
\hline
\end{tabular}

Based on the data of the overall component of cognitive load, both components of the ability to receive information obtained an average value of 59.09, mental effort of 70.7 and learning outcomes of 64.89. These results indicate that the learning strategy used has the characteristics of a high cognitive load component. In other words, students experience cognitive load in constructing cognitive schemas.

The results of the first correlation test showed a positive correlation between mental effort on the ability to receive and process information with a very weak category correlation coefficient level. The second correlation test shows that there is a negative correlation between the ability to receive and process information on learning outcomes with a correlation coefficient level of no significance with a very weak category. Then the results of the third correlation test showed a positive 
correlation between mental effort on learning outcomes with the level of the correlation coefficient being insignificant with a very weak category (Table 3 ).

Table. 3. Correlation Coefficient Between Components of Cognitive Load

\begin{tabular}{clccc}
\hline No & Correlation Between Components of Cognitive & $\mathbf{r}$ & $\mathbf{r}^{2}$ & Sig. \\
& Load & & & 0,994 \\
\hline 1 & Mental effort on the ability to receive and process & 0,00 & 0,000 & 1 \\
& information & & \\
2 & Ability to receive and process information on & - & 0,002 & 0,797 \\
& learning outcomes & 0,03 & & \\
& & 9 & & \\
3 & Mental effort on learning outcomes & 0,14 & 0,021 & 0,337 \\
\hline & Note. Sig 0.05: not significant & & \\
\hline
\end{tabular}

The results of the first regression test showed that there was no positive contribution between mental effort on the ability to receive and process information with a determination coefficient level of $0 \%$. The second regression test shows that there is a very small contribution between the ability to receive and process information on learning outcomes with a determination coefficient level of $0.2 \%$. Then the results of the third regression test showed a positive contribution between mental effort on learning outcomes with a coefficient of determination level of $2.1 \%$ (Table 1 ).

The results of statistical analysis of the measurement of the cognitive load component illustrates the difference in mean between the three components. As the results of the analysis shown (Figure 1), it is known that the component of cognitive load on the ability to receive and process information obtains an average score in the sufficient category. This illustrates that online learning activities based on moodle are quite helpful for students in understanding the diversity and classification of vertebrates in the classification of Pisces and amphibians. The high score of the ability to receive and manage information illustrates that students use their cognitive schema. The higher the student's ability to manage cognitive schemas, the lower the intrinsic cognitive load (ICL) possessed by students.

The amount of intrinsic load received is contrary to the ability to receive and manage information (Putri, 2018). However, the average results obtained in the learning activities carried out have a high intrinsic load, it can be expected because there are too many features in the Moodle-based LMS (asynchronously), including: video features, discussion forums, reading sources and assignments and the presence of The addition of asynchronous learning hours in e-learning can cause students to have to understand large amounts of material. Excess cognitive resources will cause cognitive activities cannot be carried out in working memory and can make learning difficult (de Jong, 2010).

The average result of the ability to receive and manage information is different from the average result of mental effort owned by students. Figure 1 shows that the mental effort possessed by students is in the high category. The high mental 
effort of students illustrates that the extraneous cognitive load of students is high (directly proportional). The high extraneous load is thought to have something to do with the slipt attention situation or the condition of divided students' attention (Mayer and Moreno, 2010). Online learning (asynchronous and synchronous) is very difficult to control student activities at home and focus on learning activities.

In addition, the high mental effort is possible because many learning activities are carried out using the LMS asynchronously, so that it has an impact on the mental effort carried out by students. The condition of students unable to take part in learning due to inappropriate learning stages (Siki, 2019). The average learning outcomes obtained in online learning using a moodle-based LMS show that the ability to study outcomes is in the sufficient category. This can be influenced by an increase in learning independence (Rahmawati \& Setyaningsih, 2021). In other words, the learning strategy used is thought to be able to help students manage their cognitive schemes (Brunken et al., 2010). Significance in acquiring information processing processes by linking prior knowledge and new knowledge. The structure of prior knowledge is the most important factor influencing the learning of new material. (Muamanah \& Suyadi, 2020)

The effectiveness of reducing cognitive load in a learning activity must be seen from the relationship between the three components, the high and low scores of each component of cognitive load achieved by students do not adequately represent this. The results of the correlation between mental effort on the ability to receive and process information indicate that there is a contribution of mental effort to the ability to receive and process information that is not clear, this illustrates that the possibility of students having a cognitive load. Students who have high mental effort (high ECL) tend to have low ability to receive and process information (high intrinsic load), meaning that the learning strategies provided do not help students acquire cognitive schemas (Paas et al., 2003). Learning strategies for vertebrate diversity and classification through online learning based on Moodle have not fully assisted students in obtaining information.

The results of the correlation test of the ability to receive and process information on learning outcomes show that the low ability to receive and process information contributes to improving learning outcomes, meaning that there are other aspects that contribute more to learning outcomes. If students cannot accept the information presented, they may have difficulty integrating these memories with relevant knowledge (Wahyuni \& Cahyani, 2021) or in other words students have a high cognitive load.

Furthermore, the results of the correlation test of mental effort on learning outcomes show the unclear contribution of mental effort (learning strategies) to student learning outcomes, students still have a high cognitive load. The results of the regression test showed that mental effort only contributed $2.1 \%$. It is possible that there are many factors that influence student learning outcomes. One of the factors that affect the high mental effort or extraneous burden on students is because there are too limited activities or features available in the LMS so that students feel bored because they cannot find the knowledge needed. The high 
mental effort of students is caused because students feel bored in carrying out learning (Cahyani et al., 2020). In addition, the online learning process from home (synchronous and asynchronous) makes students not focus on paying attention to learning activities. The reduced or lost focus in learning represents the high mental effort made by students (Susanto and Munandar, 2017).

Based on the results of the study, it is illustrated that the diversity and classification of vertebrates on the topic of Pisces and amphibians through online learning based on moodle has a high cognitive load for students. If students have a cognitive load that exceeds the capacity of working memory, then no matter how much mental effort (searching for alternative learning) students make, they will not get maximum learning outcomes (Sunawan et al., 2017). Therefore, educators must look for alternative learning strategies that can facilitate students in learning, especially online learning.

\section{Conclusion}

Measurement of cognitive load in vertebrate diversity and classification lectures through online learning based on moodle shows that the learning strategy used has the characteristics of a high cognitive load component. The high cognitive load obtained by students is seen from the high mental effort and the high intrinsic load owned by students, so that it has an impact on the learning outcomes obtained.

The correlation between mental effort on the ability to receive and process information shows that there is a contribution of mental effort to the ability to receive and process information that is not clear, this illustrates that the possibility of students having a cognitive load. The results of the correlation test of the ability to receive and process information on learning outcomes show that the low ability to receive and process information contributes to improving learning outcomes, meaning that there are other aspects that contribute more to learning outcomes. Furthermore, the results of the correlation test of mental effort on learning outcomes show the unclear contribution of mental effort (learning strategies) to student learning outcomes, students still have a high cognitive load.

Researchers recommend that educators look for appropriate learning strategies to facilitate online learning activities during the Covid-19 pandemic, reduce students' cognitive load by making efforts to improve learning strategies and processes, and increase motivation. For further researchers, they can follow up research on the correlation between cognitive load on student learning motivation online, both synchronously and asynchronously.

\section{Acknowledgement}

This research can be carried out properly thanks to the assistance of various parties, for that the researchers would like to thank the LPPM Pakuan University and the Pakuan Siliwangi Foundation, which have provided internal research 
grants in this research, experts who were asked for their opinion and validate the instrument and colleagues who help review the script.

\section{References}

Aminah, G. H. (2018). Sumber Belajar Materi Animalia Kelas X DI MA NU 03 Sunan Katon (Pengembangan Buku Identifikasi Vertebrata Koleksi Kebun Binatang Mangkang Sebagai Sumber Belajar Materi Animalia Kelas X di MA NU 03 Sunan Katong ). Jurnal Pedagonal, 1-90.

Arikunto, S. (2007). Dasar-Dasar Evaluasi Pendidikan (Revisi). Bumi Aksara.

Brunken, R., Seufert, T., \& Paas, F. (2010). Measuring Cognitive Load. In J. L. Plass, R. Moreno, \& R. Brunken (Eds.), Cognitive Load Theory (pp. 181201). Cambridge University Press.

Cahyani, A., Listiana, I. D., \& Larasati, S. P. D. (2020). Motivasi Belajar Siswa SMA pada Pembelajaran Daring di Masa Pandemi Covid-19. IQ (Ilmu AlQur'an): Jurnal Pendidikan Islam, 3(01), 123-140. https://doi.org/10.37542/iq.v3i01.57

de Jong, T. (2010). Cognitive load theory, educational research, and instructional design: Some food for thought. Instructional Science, 38(2), 105-134. https://doi.org/10.1007/s11251-009-9110-0

Kahfi, A. (2021). Dampak Pembelajaran Daring Di Masa Pandemi Covid 19 Terhadap Perkembangan Kognitif Anak. Jurnal Dirasah, 4(1), 14-23.

Mayer dan Moreno. (2010). Techniques That Reduce Extraneous Cognitive Load and Manage Intrinsic Cognitive Load during Multimedia Learning. In J. L. Plass, Moreno, \& Brunken (Eds.), Cognitive Load Theory (p. 131). Cambridge University Press.

Muamanah, H., \& Suyadi. (2020). Pelaksanaan Teori Belajar Bermakna David Ausubel Dalam Pembelajaran Pendidikan Agama Islam. Jurnal Pendidikan Islam, 5(01), 161-180. https://doi.org/10.29240/belajea.v5

Munandar, R. R. (2015). Pengelolaan Beban Kognitif Siswa Sesuai Gaya Belajar Dan Sosial Ekonomi Menggunakan Pembelajaran Two Stay Two Stray Pada Materi Klasifikasi Spermatophyta. Universitas Pendidikan Indonesia.

Nursit, I. (2015). Pembelajaran Matematika Menggunakan Metode Discovery Berdasarkan Teori Beban Kognitif. JPM : Jurnal Pendidikan Matematika, 1(1), 42. https://doi.org/10.33474/jpm.v1i1.403

Paas, F., Renkl, A., \& Sweller, J. (2003). Cognitive load theory and instructional design: Recent developments. Educational Psychologist, 38(1), 1-4. https://doi.org/10.1207/S15326985EP3801_1

Putri, I. I. (2018). Hubungan Komponen Usaha Mental (UM) Dan Menerima Mengolah Informasi (MMI) Pada Proses Pembelajaran Biologi. Bioilmi: Jurnal Pendidikan, 4(2), 53-61.

Rahmawati, L. E., \& Setyaningsih, V. I. (2021). Kemandirian belajar siswa dalampembelajaran daring mata pelajaran bahasa Indonesia. Kembara: Jurnal Keilmuan Bahasa, Sastra Dan Pengajarannya, 7(2), 353-365. https://doi.org/10.22219//kembara.v7i2.16326 
Rizvialdi, \& Sidarta, N. (2019). Pengaruh aktivitas fisik terhadap kapasitas memori kerja pada pelajar SMA. Jurnal Biomedik Dan Kesehatan, 2(2), $58-64$.

Siki, F. (2019). Problematik Strategi Pembelajaran Bahasa Indonesia. Jubindo: Jurnal Ilmu Pendidikan Bahasa Dan Sastra Indonesia, 4(2), 71-76. https://doi.org/10.32938/jbi.v4i2.213

Sunawan, S., Yani, S. Y. A., Kencana, T. I., Anna, C. T., Mulawarman, \& Sofyan, A. (2017). Dampak Efikasi Diri terhadap Beban Kognitif dalam Pembelajaran Matematika dengan Emosi Akademik sebagai Mediator. Jurnal Psikologi, 44(1), 28. https://doi.org/10.22146/jpsi.22742

Suriadi, H. J., Firman, \& Ahmad, R. (2021). Analisis Problema Pembelajaran Daring Terhadap Pendidikan Karakter Peserta Didik. Edukatif: Jurnal Ilmu Pendidikan, 3(165-173).

Susanto dan Munandar. (2017). Model Project Based Learning Sebagai Upaya Mengelola Cognitive Load Mahasiswa Semester V Pada Materi Media Audio Visual. Jurnal Ilmiah Pendidikan, 1(2), 100-109.

Wahyuni, S., \& Cahyani, Y. (2021). Beban Kognitif Mahasiswa dalam Pembelajaran Daring di Masa Pandemi Covid-19. Jurnal Penelitian Kesehatan Suara Forikes, 12(April), 21-26.

Wantika, R. R. (2017). Pembelajaran Kooperatif Tipe TAI Berdasarkan Teori Beban Kognitif. Jurnal Buana Pendidikan, 13(23), 43-48.

Wardika, K. W., Ariawan, K. U., \& Arsa, P. S. (2017). Penerapan Model Core (Connecting, Organizing, Reflexting, Extending) Meningkatkan Hasil Aktivitas Belajar Perakitan Komputer Kelas XTkj2. Jurnal Pendidikan Teknik Elektro Undiksha, 6(3), 127-136. https://ejournal.undiksha.ac.id/index.php/JJPTE/article/view/20856

How to cite this article:

Munandar, R. R., Rostikawati, T., \& Susanto, L. H. (2022). Cognitive Load Lecture on Diversity and Classification of Vertebrates Through Moodle-Based Online Learning. Journal of Educational Sciences, 6(1), 107-115. 